his L'Évolution religieuse contemporaine chez les Anglais, les Américains et les Hindous (Paris, 1884), Les Religions et les Philosophies dans l'Asie Centrale (3rd ed., Paris, 1900), and La Migration des Symboles (Paris, 1892). The last-named attracted the widest attention, and an English translation appeared in 1894 with an enthusiastic introduction by Sir George Birdwood. In Ce que l'Inde doit à la Grèce (Paris, 1897) he summed up judiciously the pros and cons of this much-debated theme.

The "History of Religions" is a subject still provocative, and perhaps not least in Belgium, of controversy, and a department in which it is difficult to reach firm and precise conclusions. Count Goblet d'Alviella excelled in the assembling of evidence and in graceful and judicious exposition.

F. W. Thomas.

\title{
Sir Ramkrishna Gopal Bhandarkar, M.A., Hon. Ph.D., K.C.I.E.
}

Ramkrishna Gopal Bhandarkar, who died in his home in Poona on August 24, was the last survivor of a group of Sanskrit scholars which had lent distinction to the Bombay Presidency during the concluding thirty years of the nineteenth century. Beside his own countrymen, Shankar Pandit, K. T. Telang, Bhagwanlal Indraji, A. V. Kathavate, Pandit Durgaprasad and others, the group included such leading scholars as Colonel Jacob, Bühler, Kielhorn, Peterson, and Fleet, with all of whom Bhandarkar may be brought into connexion. Like Bühler, Kielhorn, and Peterson, he took a prominent part in that branch of research which consists in the discovery and record of Sanskrit MSS.; and of the numerous reports published by the Bombay Government none have a higher value than his. In common with the same triad and with Fleet he made important contributions to the study of inscriptions and of the historical and archrological material contained in them. Like Kielhorn, he was at home in the texts of the Sanskrit grammarians, and he published some 
valuable articles concerning the interpretation, and the dating, of Pānini and his commentators; while his Wilson Lectures, delivered in the Bombay University (in 1877, and partly printed in the Bombay Asiatic Society's Journal, but not published in full until 1914), are important for the history of linguistic development in India, and contain many original observations. Like Colonel Jacob, he was interested in religious philosophy; he lectured on Indian theism, and his work on Vaishnavism, Saivism, and Minor Religious Sects (in the Grundriss der Indo-Arischen Philologie, 1913) is a thorough exposition of the religious history of Hinduism. In the editing of texts he was less active than his countrymen Shankar Pandit, K. T. Telang, and others; but his edition of Bhavabhūti's Mālatī-Mādhava (Bombay Sanskrit Series, 1876, ed. 2, 1905) is the standard presentation of that drama. His First Book of Sanskrit and Second Book of Sanskrit have passed through very many editions (English and Gujarati), and have been the basis of elementary Sanskrit teaching in Bombay.

Bhandarkar was therefore an all-round scholar. Most of his work was of the nature of research, i.e. the discovery of new facts and new ideas regarding their co-ordination. His most considerable labour of systematization is contained in his "Early History of the Deccan" (1884), contributed to the Bombay Gazetteer, and the before mentioned monograph on Vaishnavism, Saivism, etc. His Peep into the Early' History of India, though it propounded a now untenable chronological theory, contains much valuable matter in detail. Everything that he wrote was marked by independent knowledge and judgment and good sense. Consequently he had very little to retract, and in regard to one or two controversial matters, such as the date and interpretation of Patañjali, and the epoch of the Gupta Era, he took the right view from the first. Although he defended the indigenous Sanskrit scholarship from unjust depreciation, he never wavered in his fidelity to critical principles; the sound position which he. 
adopted in his address on The critical, comparative, and historical methods of inquiry as applied to Sanskrit scholarship and philology and Indian archoology is maintained in his last published utterance. In his old age, when restricted to a recumbent posture, he retained the brightness of his intellect and a keen interest in the progress of Sanskrit studies, which was cheering to witness. To the Bhandarkar Memorial Institute, founded at Poona in 1917 (opened by Lord Willingdon) to commemorate his eightieth birthday, and charged with the keeping of the government collections of Sanskrit MSS.-amassed during a period of fifty years-he contributed not only his library of about 3,000 volumes, but also a manifest, and, we may hope, enduring, inspiration. The R. G. Bhandarkar Commemoration Volume, presented to him by the Institute on that occasion, contained contributions from about forty scholars-but for the war conditions it would have been of still greater extent. At the First Oriental Conference, held at Poona in 1919, and opened by Sir George Lloyd, as Governor, he was described as being to the young scholars who had organized the Institute "an ancient Riși incarnate, a man of pure convictions and courage, an example of purity of life, purity of thought, and purity of action". His Presidential Address, read in his absence (through illness), was an enlightening survey of the field of study, closing with a note of congratulation upon the growth of critical scholarship in India and of firm confidence in its future. The large number of excellent papers read at the Conference may bring home a like conviction even to those who might otherwise not adequately realize the activities of the present generation of Indian Sanskritists.

Much of Bhandarkar's work was published in the form of articles contributed to the Indian Antiquary (vols. i-xvi), the Journal of the Bombay Branch of the Royal Asiatic Society, Epigraphia Indica, and the Proceedings of the Oriental .Congresses of 1874 and 1886. His one contribution to this Journal is to be found in the volume for 1910. As regards 
educational matters, we may mention his Convocation Address (1894) as Vice-Chancellor of the Bombay University and-his evidence before the Education Commission of 1882. In 1883 he delivered a lecture to the Poona Prarthana Samaj on The Basis of Theism and its relation to the so-called revealed religions.

The stages in Bhandarkar's career commence with his student life at Ratnagiri High School (he was the son of a Brahman official in the district), and at Elphinstone College, Bombay (1847-58). After graduating with the highest honours (1862) he was elected to one of the Dakshina Fellowships, which he held during 1859-64, receiving from Dr. Haug the foundation of his work in Comparative Philology. During 1864-8 he served as Headmaster of High Schools. He was then called to succeed Bühler as Professor of Sanskrit in Elphinstone College (1869-81), after which he was transferred to the Deccan College, Poona, as Professor of Oriental Languages (1882-93) in succession to Kielhorn. During two years (1893-4) he was Vice-Chancellor of the Bombay University. He then retired, at the age of 55 , from Government service. In connexion with Lord Curzon's educational plans he was called in 1903 to the Viceroy's Legislative Council, and from 1904--8 he represented the Bombay University upon the Legislative Council of the Province. He attended the Orientalist Congresses of 1874 and 1886, and of the second of these he contributed to the Bombay Society's Journal his impressions-an elaborate appreciation. His honorary distinctions include the Honorary Membership of this Society (1885), and of the sister societies in Germany (1887) and America (1887); the Fellowship of the Calcutta University (1887); the membership of the French Institute ; the Hon. LL.D. of the Bombay University; and the Hon. Ph.D. of Göttingen and Calcutta; the C.I.E. (1889) and K.C.I.E. (1911). Of his three sons one, who follows the medical profession, attended his father in his last illness; a second was Shridhar R. Bhandarkar, Professor of Sanskrit in Elphinstone College; while the youngest, Devadatta $R$. 
Bhandarkar, is the well-known Carmichael Professor of Ancient Indian History and Culture in the Calcutta University.

F. W. Thomas.

\section{Professor Albert T. Clay}

In Professor Albert T. Clay, who died last September at a comparatively early age, American Assyriology has lost one of its foremost scholars. He began his Assyriological work in the best of schools by copying and editing the original tablets of the great Nippur library, which are now in the Museum of Philadelphia. His copies of the tablets of the Kassite period with their careless and sometimes semi-legible writing are especially noteworthy ; in fact, his copies generally of the cuneiform texts are among the best ever made.

$\mathrm{He}$ was an indefatigable worker, and his contributions to science and our knowledge of Babylonian literature are very numerous. He first brought to light and published one of the most important Syllabaries bequeathed to us by the Babylonian scribes, and the number of new historical texts which we owe to him is large. In 1915 appeared his Miscellaneous Inscriptions in the Yale Babylonian Collection, which formed the first volume of the Babylonian Texts in the Yale Oriental Series, and included the interesting inscription of Nabonidos in which the royal antiquary tells us that the daughter of Kudur-Mabuk was the first abbess of the nunnery in the temple of the Moon-god at Ur. Professor Clay had already published many of the cuneiform texts in the Pierpont Morgan Library, which he had been instrumental in securing (Babylonian Records in the Library of J. Pierpont Morgan, 1913), and many more were published by him in a later volume which appeared in 1923.

But Professor Clay is probably best known as the propounder and advocate of a theory which seeks to establish the existence of a Semitic "Amorite" empire preceding that of the Baby- lonians and originating much of the culture which is usually believed to have come from a Babylonian source. In 